\title{
Pedagogical innovation in higher education and active learning methodologies - a case study
}

\author{
Andreia Carvalho \\ ISAL, Funchal, Portugal \\ Sergio Jesus Teixeira \\ Management and Economics, ISAL, Funchal, Portugal \\ Leonilde Olim and Sancha de Campanella \\ ISAL, Funchal, Portugal, and \\ Teresa Costa \\ UMa, Funchal, Portugal
}

\begin{abstract}
Purpose - The aim of this study is to obtain a broader knowledge of innovative pedagogical practices in higher education, by analysing the particular case of the Higher Institute of Administration and Languages (ISAL). The literature review reveals a gap in this scientific field, and filling this gap is as imperative as the need to articulate higher education with the Students' Profile by the End of Compulsory Schooling.

Design/methodology/approach - This research adopts a qualitative methodological approach, in order to analyse the students and teachers' perceptions of the active learning methodologies implemented at ISAL. Data were collected from a closed-ended questionnaire, aimed at a population composed of students and teachers. Findings - The literature review reveals a gap in this scientific field, particularly in Portugal. Filling this gap is as imperative as the need to articulate higher education with the Students' Profile by the End of Compulsory Schooling.

Practical implications - With the adoption of this methodological approach, this research intends to verify not only whether the innovative pedagogical practices addressed in the literature review are implemented in this institution, but also to identify obstacles to their implementation. With regard to the results, several pedagogical innovation practices are already implemented, even though some limitations to their implementation are identified. Originality/value - This research allows identifying indicators that are essential to outline an intervention plan in the pedagogical practices implemented at ISAL or other higher education institutions and contributes to assessing the current state of pedagogical practices in higher education.
\end{abstract}

Keywords Knowledge, Pedagogical innovation, Higher education, Tourism, Flexibility, Active learning methodologies

Paper type Case study

\section{Introduction}

A society in constant change requires a great capacity for adaptation and updating in the face of new education systems. With regard to higher education, it is the last stage of preparing students for their integration into the world of work. Therefore, it should ensure the development of reflective and critical citizens, capable of building and mobilizing knowledge to solve problems, to create and implement ideas and projects, in a knowledge-based society that values skills (Miranda, 2007; Melo, 2017).

This responsibility of higher education in preparing citizens capable of facing the challenges of the 21st century is reinforced by changes in the legal regulations that regulate

The authors wish to thank the Portuguese Foundation for Science and Technology (Scholarships and NECE- UIDB / 4630/2020) provided support for this study, to the ISAL Research Center and to the Higher Institute of Administration and Languages - ISAL. The authors would like to thank the comments of the reviewers of this article, which contributed a lot to raise the quality of this study.

Received 29 May 2020 Revised 7 September 2020 Accepted 4 November 2020
Pedagogical innovation in higher education

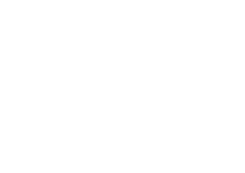


basic and secondary education, namely with the publication of the Order No. 6478/2017, of 26 July, which establishes the Students' Profile by the End of Compulsory Schooling and the Decree-Law No. 55/2018, of 6 July, which regulates the process of Curricular Autonomy and Flexibility in Primary and Secondary Education. These norms aim at building compulsory schooling whose pedagogical practices are based on basic principles such as active learning, interdisciplinarity, collaborative work and the development of metacognitive and socioemotional skills. It is expected that, by the end of secondary education, the student has had the opportunity to develop a set of values and skills "that will allow them to respond to the complex challenges of this century and to face the unpredictability resulting from the evolution of knowledge and technology." (Martins et al., 2017).

At that time, it will be up to higher education to guarantee continuity of pedagogical practices focussed on the student and on the development of knowledge and practical skills, under the risk of causing a regression in the development path of students, if they are forced to return to a learning system of fragmented knowledge, focussed on the teacher and privileging the product of knowledge, to the detriment of its process of construction (Rodrigues and Patrocínio, 2018). Bearing in mind this extremely relevant role that higher education plays in developing students' knowledge and skills, this study focusses specifically on the implementation of learning methodologies in higher education.

Despite the urgency of shifting the educational paradigm, this shift does not occur quickly. It involves, among many other aspects, a change in teachers' mentalities, continuous training and a reflective and critical culture regarding their practices (Casanova, 2014).

Research in the field of pedagogy has been emphasizing the importance of implementing methodologies based on active methods in higher education. In this context, some pedagogical experiences have already been reported, proving the existence of a connection between the active and participatory learning environments, the motivation of students and the depth of the learning experiences carried out.

However, there are still few studies on this matter, and it is essential that more research is promoted in the higher education institutions (HEIs), in order to diagnose and improve their pedagogical procedures, meeting the profile of the student/citizen of the 21st century (Nóvoa and Amante, 2015; European Commission, 2017). In fact, higher education is often criticized for being disconnected from real-life problems. Given the importance of innovation-related capabilities for contemporary organizations, the approach proposed in this study may be a way to bridge the gap between higher education and practice (Acar and Tuncdogan, 2019; Teixeira et al., 2019).

It is in this context that the present study is addressed, with the aim of obtaining a broader knowledge of pedagogical innovation practices in higher education, by analysing the specific case of the Higher Institute of Administration and Languages (ISAL). In a more specific way, this study aims at the identification of potentialities and weaknesses, for further reflection and intervention in order to improve practices. Even though the results of this study are restricted to the regional context, similar potentialities and weaknesses can be explored by other HEIs.

The more we know about innovative pedagogical practices and the more we improve the teaching-learning process, the better we can prepare students to integrate into the world of work. Bearing in mind the scarcity of studies on the pedagogical practices currently in force in higher education in Portugal, this study intends to make a contribution to fill this gap, providing good practices to be implemented in national and international HEIs.

Taking into account the aforementioned aspects, four research questions were defined, as listed as follows.

$R Q 1$. How frequent is the use of active methodologies in ISAL's degrees?

$R Q 2$. How prepared and receptive are teachers and students for the implementation of these methods? 
RQ3. What is the students and teachers' perception of the pedagogical practices implemented?

RQ4. What obstacles does the implementation of these methodologies face?

This study is organized as follows: in section 2, there is a literature review regarding the concepts intrinsic to pedagogical innovation and active learning methods; section 3 presents the main methodological aspects adopted; finally, the results and the main conclusions appear in sections 4 and 5 , respectively.

\section{Theoretical framework}

When discussing higher education, it is important to discuss andragogy, a European concept imported to the USA by Malcolm Knowles in the late 1960s (Merriam, 2017). He introduced this concept as "the art and science of helping adults learn" (Knowles, 1980). Even though there has always been an implicit understanding that adults can learn, it was not until the 20 th century that research paid attention to learning in adulthood. These early studies led adult education to achieve its own identity as a field of practice separate from childhood education (Merriam, 2017).

Knowles outlined five assumptions underlying andragogy. These assumptions depict the adult learner as someone who can direct his or her own learning, has accumulated life experiences that are a rich resource for learning, has learning needs closely related to changing social roles, is problem-centred and interested in the immediate application of knowledge and is motivated to learn by internal factors. From these assumptions about adult learners, Knowles (1980) proposed a model for designing, implementing and evaluating educational experiences with adults. Knowles suggested that the adult classroom should be a place suitable for adults, where there is "a spirit of mutuality between teachers and students as join inquirers". Moreover, since adults manage other aspects of their lives, such as family and work, they are capable of directing their own learning (Merriam, 2017). For Houle (1996), what is noteworthy is that andragogy has raised awareness among educators of the fact that they "should involve learners in as many aspects of their education as possible and in the creation of a climate in which they can most fruitfully learn".

However, Knowles came to realize that these assumptions were not necessarily true of all adults. He believed there was a continuum ranging from teacher-directed pedagogy to student-directed learning (andragogy), and both approaches are appropriate with adults and children, depending on the situation. This resulted in andragogy being defined more by the learning situation than by the learner.

In fact, in recent years, the Bologna Process has significantly changed teaching, learning and assessment methods in higher education and has led to a transformation in the role of students and teachers, giving the former a more active role in the construction of their learning and the latter the responsibility to create conditions for that to happen (Alves et al., 2012; Acar and Tuncdogan, 2019).

In the current context, it is essential that HEIs are able to deal with the demands of society, the evolution of scientific knowledge and the challenges of employability and entrepreneurship (Alves et al., 2012).

To adapt to the paradigmatic changes proposed by the Bologna Process, many of these institutions have invested in non-classroom teaching methodologies, diversifying their training offer and instilling in the student an active role in their own learning. However, motivating students to learn and to participate in the proposed activities presupposes giving meaning to these activities (Biggs and Tang, 2007).

Although the changes implemented by the Bologna Process are concluded in terms of organization of curricular plans, these are still to be implemented in the context of the
Pedagogical innovation in higher education 
pedagogical activities developed in the HEIs (Ascenzo, 2020). Despite the effort of the faculty to adapt their methodologies to the new pedagogical requirements, it is still necessary to promote the use of active methodologies (Ramos et al., 2013).

The relationship between learning outcomes, teaching-learning methodologies and the evaluation process has been the subject of study by Houghton (2004) and Biggs and Tang (2007), who evoke the concept of constructive alignment applied to higher education. This system assumes that the curriculum is created so that the learning activities and the assessment are consistent with the learning objectives that are intended to be achieved in a given curricular unit. Thus, the focus of training moves from teaching to learning (Zabalza, 2003).

In order to mitigate the excessive compartmentalization of knowledge, Morgado and Tomaz (2010) refer to the role of curricular articulation, which appears as an opportunity to "interconnect knowledge from different fields of knowledge in order to facilitate the acquisition, on the part of the student, of a global, integrating and integrated knowledge"(Morgado and Tomaz, 2010). Only then will the student be able to develop a set of technical and transversal skills, ensuring a competitive professional profile (Alves, 2003), capable of meeting the demands of the current job market (Andrews and Higson, 2008).

Conservative teaching models, based on the transmission and memorization of information, have been rethought and contradicted by collaboration and dialogue among students and between students and teachers. Thus, the teacher is no longer the holder of knowledge and the student is no longer seen as a blank sheet, ready to absorb all the information transmitted (Freire, 2014; Acar and Tuncdogan, 2019; De Castro, 2020).

In the emerging pedagogical models, the teacher adopts the role of the facilitator of the teaching-learning process, encouraging students to be autonomous and to assume a central role in this process (Masetto, 2012; Freire, 2014). The student, in turn, is no longer merely a passive recipient of the information transmitted and is included in the decision-making process regarding his/her training. This inclusion makes the student co-responsible in the creation of pedagogical innovations (Delors et al., 1998; Leite and Zabalza, 2012; Freire, 2014; Moran et al., 2013).

In this perspective, the use of expository methods essentially centred on the teacher is a characteristic of the traditional teaching model. In the new educational context, it is important that the pedagogical activity is oriented towards the adoption of techniques and activities that encourage student participation (Esteves, 2010; Leite and Ramos, 2010; Ramos et al., 2006).

Therefore, learning should be centred on what the student is able to do, motivating autonomous and cooperative work and, thus, developing fundamental soft skills, such as the ability to work as a team.

This focus on the student's abilities, characterized by innovative teaching methods, contradicts the more traditional models, as it encourages the student to seek knowledge autonomously, developing his/her creativity and critical analysis, through problem-solving (Vieira et al., 2008; Attard et al., 2010).

To make learning meaningful, Freinet (2004), Morin (2013) and Freire (2014) argue that the knowledge previously acquired by students can be considered in the classroom. This sharing of knowledge between students and teachers can facilitate the acquisition and consolidation of new information, surpassing the mere memorization of it (Gadotti, 1995; Teixeira et al., 2019).

According to Kenski (2012) and Sales and Leal (2018), the introduction of new technologies can contribute to the construction of knowledge that is not based only on the transmission and memorization of information, but on its understanding, as it provides new ways of teaching and learning and facilitates interaction between students and teachers, in addition to stimulating student learning, creativity and autonomy.

Similarly, Lévy (2010) highlights the importance of combining the incorporation of new technologies into the educational context with new teaching practices, thus avoiding the 
simple reproduction of conservative pedagogical methods, even when these methods may seem modern.

In fact, innovative pedagogical practices in higher education have been increasingly the subject of discussion and research (Behrens, 2005; Lévy, 2010; Leite and Zabalza, 2012). In the context of higher education, pedagogical innovation does not only require a disruption of the conservative teaching models but also of the university's own role, which has long been consolidated as a producer and holder of knowledge and which has been little adapted to the structural changes that have occurred in the teaching process over time (Leite and Zabalza, 2012; Masetto, 2012).

Bearing in mind this resistance to change, the implementation of innovative teaching practices represents a challenge for higher education (Araújo and Belian, 2018; Masetto, 2012; Dias, 2005). Pedagogical innovation, therefore, needs to be strengthened in higher education and discussed by all those who participate in the teaching and learning process, betting on continuity and permanent innovation (Araújo and Belian, 2018).

Innovation has been applied in practically all study areas given its important application at present (Aristei et al., 2016; Cervantes, 2017; Chaudhary, 2017; Fernandes and Ferreira, 2013; Franco and Pinho, 2018; Fukugawa, 2016; Koman and Kundrikova, 2016; Li, 2017; Serbanica et al., 2015; Zheng et al., 2017). Innovation means creating something new, and it refers to an idea, method or object that is created and based on previous standards. Nowadays, it is more used in the context of ideas and inventions as well as related economic exploitation, and innovation is an invention that arrives on the market. According to some authors, innovation is the process that includes technical activities, design, development, management that results in the commercialization of new or improved products, technical practices or products. Innovation can also be defined as doing more with fewer resources, as it allows for efficiency ranges in processes, whether productive or administrative, pedagogical or financial, in the provision of services or in teaching methodologies in order to make it more efficient and be a driving force for competitiveness (Amado et al., 2017; Cervantes, 2017; Fernandes and Ferreira, 2013; Franco and Pinho, 2018; Lee et al., 2016; Serbanica et al., 2015; Teixeira et al., 2018). da Silva (2018) suggests that higher education teachers use two or more active learning methodologies, in order to stimulate an active and constructive learning environment. However, it is important to note that the choice, combination and application of these methods during classes, by themselves, do not guarantee effective learning. The success of the teaching-learning process depends on the combination of four didactic elements: the planning and setting of educational objectives; the definition and organization of content; the choice of teaching strategies; and the evaluation process (Haydt, 2006; Piletti, 2010; Gil, 2011; Rodrigues et al., 2011; Liblik, 2012; Malheiros, 2012; Belther, 2014; Gil, 2015).

In the next section of this study, some active learning methodologies are presented.

\subsection{Differentiated instruction}

More than a teaching method, differentiated instruction is a strategy that promotes the "diversification of materials and learning styles, for a group of students with heterogeneous needs, but with common goals" (Perraudeau, 1997). According to Fresne (1994), this is "a teaching practice that respects the differences between individuals and that tries to organize learning according to each one". This method uses strategies that allow differentiation in the classroom, depending on the levels and difficulties of each student, having as main objective their success in learning. For this, it is necessary that the teacher knows the students and does not focus only on the weakest, differentiates the contents of the training programme, promotes teamwork in spaces conducive to collaboration and defines with the students different working modalities (Feyfant, 2016). Bearing in mind that students have different learning rhythms, one of the practices adopted is the differentiation of tasks

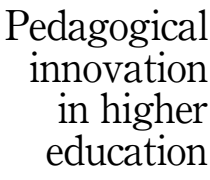


assigned to students who have learning difficulties and those who can progress more quickly (Feyfant, 2016). In this way, each student is "confronted with didactic situations that are beneficial to them" (Perrenoud, 2005).The organization of the room can favour the differentiation of learning, which implies rethinking "the classroom (layout of tables and chairs, accessibility to resources), facilitating work in groups” (Feyfant, 2016).

\subsection{Group work}

Group work plays an important role in the classroom, as it creates the opportunity for dialogue and exchange of information. In this dynamic of work, the student interacts, analyses, questions, argues, justifies and evaluates (Haydt 2006). According to Haydt (2006), "the main objectives of group work are: to facilitate the construction of knowledge; to allow the exchange of ideas and opinions; and, to enable the practice of cooperation for a common purpose". According to Piletti (2010), this technique has three stages: "planning (determining the objectives, alternatives and resources to achieve the purposes and defining the roles of each student); group action (execution of the planned action, with data and material collection, data preparation and conclusions to be presented in the form of a report or seminar); and, evaluation (checking if the objectives were achieved and if the performance of each student corresponded to the group's expectations)".

\subsection{Cooperative and collaborative work}

According to Boavida and Ponte (2002), one cannot assume that is facing a situation of collaboration simply because several people are working together. Therefore, it is important to distinguish collaboration (co-elaborate, jointly elaborate) from cooperation (co-operate, operate together). This distinction is associated with the roles of the participants. A group with a strong hierarchical nature does not develop collaborative work, since collaboration presupposes that the actors work on an equal and mutual basis, in order to deepen their knowledge in a reciprocal manner. Collaboration also requires joint decision-making, the promotion of dialogue, sharing and mutual learning. Cooperation, on the other hand, concerns the simple joint execution of several operations. Although different, these terms are nonetheless complementary: collaborative work can involve cooperative work (carrying out certain operations together). In the educational sciences, cooperation presupposes that a specific working group assigns a task to each element. This division of tasks, which can be done by the teacher himself/herself, is clear and all elements must carry out their task so that the objective is achieved. However, this division makes students work in isolation most of the time. Collaboration, in turn, provides for the intervention of all team members in decision-making, which implies negotiation, with no clear purpose for dividing specific tasks. A truly collaborative project is one that involves all participants. In this context, the teacher does not intervene so much in decisions. Although cooperative learning is effective and beneficial, the teaching model still privileges the individual potential of students. This sharing allows teachers to learn from each other, expand their skills and enrich each other's practice. However, the lack of time and/or resources and the division of the curriculum by subjects are at the root of the lack of joint initiatives by teachers. In short, collaborative work allows one to face the challenges of the current society and contributes to richer and more meaningful learning.

\subsection{Case study}

A case study can be described as a real, fictional or adapted narrative of reality that serves as an object of study in the classroom. This narrative aims to put into practice the knowledge acquired by students on a given topic. This method involves the analysis of problems and decision-making by the student and allows contact with situations that can 
be encountered in the practice of their profession. The use of case studies allows both the teacher and the student to contribute to the learning process. Although the teacher is more familiar with case studies than the students, their knowledge is not taken for granted, as the students present new perspectives on the issues addressed. For the learning process to be meaningful and include the student, the theme worked on must relate to the knowledge previously acquired by the student (Peixoto, 2016).

\subsection{Problem-based learning and problem-solving method}

Problem-based learning consists in solving a problem about which the students have not received prior information, which will force them to discover for themselves the problems and possible resolutions. The students thus assume a major role in the search for information and knowledge. The teacher, in turn, becomes an advisor, facilitator, supporting students in the process of solving the case, but not teaching in a conventional way. It is the student who, in his/her attempt to solve the case, learns the subject (Kaplan, 2014). From this method, the problem-solving method derives, which corresponds to the presentation of problematic situations to students, so that they can propose a solution, through the knowledge they already have or the search for new information (Haydt, 2006; Belther, 2014). This method promotes reflection and dialogue between students and between students/teachers. Thus, the student stops being a passive listener and adopts an active posture in the learning process, developing his/her critical analysis and creativity (Belther, 2014).

\subsection{Role play}

Role play is a simulation technique in which students represent a situation, in a planned or spontaneous way. For it to be effective, it is important that there is "clarity of the content to be worked on and educational objectives established". (Haydt, 2006; Malheiros, 2012). Malheiros (2012) warns of the need for the teacher to know well the group of students to whom he/she applies this technique, since very shy groups may feel intimidated and very restless groups may have difficulty concentrating. Due to the intense emotional involvement that the activity entails, it is necessary for the teacher to adopt some precautions, especially with students who do not know how to deal with conflicts and group situations (Haydt, 2006).

\subsection{Blended learning}

Digital information and communication technologies have been changing the dynamics of the classroom. This integration of technologies in classroom activities has provided what is known as blended learning or hybrid teaching (Valente, 2014). Hybrid teaching combines face-to-face and distance activities, carried out using technologies. This methodology has been used in higher education to reconcile moments when the student studies the contents using online resources and others when teaching takes place in a classroom, with the interaction between students and teachers. The face-to-face part must necessarily have the supervision of the teacher, value interpersonal interactions and be complementary to online activities, providing a more efficient, stimulating and personalized teaching and learning process (Valente, 2014).

\subsection{Flipped classroom}

The inverted classroom is a mixed learning modality, in which the content is studied practically before the student attends the class. In this way, the classroom becomes an active learning space, where the contents already studied are worked on and practical problemsolving activities, projects and group discussions are carried out, with the support of the teacher and the collaboration of colleagues. (Valente, 2014). The teacher works with the students' difficulties, instead of presenting the content of the course (Educause, 2012). According to the report Flipped Classroom Field Guide (2014), the basic rules for the inversion 
of the classroom are as follows: "1) Classroom activities involve a significant amount of active learning to question, solve problems and other activities, forcing the student to retrieve, apply and expand the material learned online; 2) Students receive feedback immediately after the activities in the classroom; 3) Students are encouraged to participate in online and face-to-face activities, which are computed in the student's formal assessment, that is, they are worth a grade; 4 ) both the material to be used online and the learning environments in the classroom are highly structured and well planned" (Valente, 2014).

\section{Methodology}

\subsection{Data and methods}

This study adopts a qualitative methodological approach. According to Flick (2005), qualitative research recognizes and analyses the different perspectives of the participants. In fact, one of the objectives of this study is to analyse teachers and students' perceptions of active learning methodologies. In addition, the qualitative approach includes the researcher's reflections on the research (Flick, 2005). Rather than measuring the variables involved in the phenomenon being studied, this paper intends to understand that phenomenon and its context. Moreover, the research questions of this study are best answered using a qualitative approach since it allows the researcher to obtain insights and interpretations rather than hypothesis testing (Sampieri et al., 2006).

This research analyses the specific case of the ISAL, therefore a case study methodology is adopted. Yin (2003) describes this methodology as an empirical inquiry that investigates a contemporary phenomenon in depth within its real-life context. Anderson (1993), in turn, sees case studies as a methodology that allows the investigation of the differences between what was planned and what actually occurred. Actually, with this methodological approach, it is intended to verify whether the pedagogical innovation practices addressed in the literature review are implemented in the teaching practices of the unit of analysis.

Data were collected from a closed-ended questionnaire, composed of 12 questions, designed using Google Forms and a Likert-type scale ranging from 1 to 5 (see Appendix). In order to outline the profile of the respondents, four identifying questions were defined: profession (student/teacher), age, municipality and field of study/teaching. The questionnaires were addressed to a sample composed of students and professors attending or teaching higher education courses at ISAL in the academic year 2019/2020. The sample consists of 148 respondents, of whom 11 are teachers and 137 are students. Respondents are between 18 and 55 years old, from 11 municipalities and attend or teach degrees in Tourism, Hotel Organization and Management and Business Management.

\subsection{Characterization of the unit of analysis}

ISAL has its origins in 1984, when its founder "Cénil - Centro de Línguas, Lda” was established in Funchal, on the island of Madeira (Portugal). It is important to mention that in the Autonomous Region of Madeira there are only three HEIs, of which two are private polytechnics (ISAL and the Escola Superior São José de Cluny) and one is a public university (University of Madeira). In 1989, ISAL was recognized as a HEI. In that year, its private higher education study plans were approved and the value of the diplomas conferred by the courses taught in this institution was recognized. It was the first HEI in the Autonomous Region of Madeira with higher education courses in Tourism Techniques and Organization and Tourism Management, created in the academic year 1989/1990, and in Business Management. Since then, ISAL has developed, in addition to higher education courses in Tourism and Management, complementary or related activities, namely in the fields of improvement and consultancy in Management and Tourism. In 2005, ISAL received authorization to teach its first degree. It was a 
historic landmark, for the first time in the Autonomous Region of Madeira a Degree in Tourism was created. In 2006, ISAL started a new project: Post-Graduations. In that year, a postgraduate course in Hotel Management was developed. ISAL provides new Post-Graduations annually in key areas, always with the objective of meeting the needs of the region. The academic year 2007/ 2008 was highlighted by the implementation of the Bologna process, with ISAL offering four degrees: Business Management, Hotel Organization and Management, Tourism and Accounting and Finance. ISAL has, therefore, three major areas of activity: Management, Tourism and Hospitality, which is why currently it has only three higher education courses: Business Management, Tourism and Hotel Organization and Management.

Currently, in the academic year 2019/2020, in its higher education courses, ISAL has a total of 242 students, of whom 104 are attending Tourism, 82 Hotel Organization and Management and 56 Business Management, as shown in Table 1. It is important to mention that the first year of the Higher Education Course in Business Management was not opened.

In the current academic year 2019/2020, ISAL provides three Post-Graduations in Management: one in Human Resource Management, another in Management and Public Administration and another in Management of Health Services and Social Institutions, with a total of 41 students, as shown in Table 2 :

With regard to the teachers lecturing in the academic year 2019/2020, ISAL had 17 teachers in the first semester and 13 teachers in the second semester.

\section{Results}

Four research questions were defined:

\subsection{RQ1. How frequent is the use of active methodologies in ISAL's degrees?}

In order to answer this question, it is important to first analyse how relevant pedagogical innovation is to students and teachers. The results show that $32.4 \%$ of the respondents consider pedagogical innovation to be extremely relevant, $43.2 \%$ very relevant, $23.6 \%$ relevant and only $0.7 \%$ not relevant. None of the respondents $(0 \%)$ considered pedagogical innovation to be slightly relevant. The results indicate that the majority of ISAL's teachers and students attach relevance to innovation in the field of pedagogy.

Regarding the use of active learning methodologies, the results show that for $45.9 \%$ of the respondents these methodologies are frequently used, for 35.8\% occasionally used and for $15.5 \%$ very frequently used. Only $2.7 \%$ of the respondents consider the use of these methodologies to be rare. None of the respondents stated that active learning methodologies are never used. Therefore,

\begin{tabular}{|c|c|c|c|c|c|}
\hline $\begin{array}{l}\text { Course and academic } \\
\text { year }\end{array}$ & Tourism & $\begin{array}{c}\text { Hotel organization and } \\
\text { management }\end{array}$ & $\begin{array}{c}\text { Business } \\
\text { management }\end{array}$ & $\begin{array}{c}\text { Total per } \\
\text { year }\end{array}$ & \\
\hline First year & 24 & 27 & & 51 & Table 1. \\
\hline Second year & 32 & 22 & 34 & 188 & Number of students in \\
\hline Third year & 48 & 33 & 22 & 103 & the academic year \\
\hline Total cycle & 104 & 82 & 56 & 242 & study cycles $2019 / 2020$ \\
\hline
\end{tabular}

\begin{tabular}{lccrc}
\hline $\begin{array}{l}\text { Number of } \\
\text { students }\end{array}$ & $\begin{array}{c}\text { Management of health services and } \\
\text { social institutions }\end{array}$ & $\begin{array}{c}\text { Human resource } \\
\text { management }\end{array}$ & $\begin{array}{r}\text { Public administration and } \\
\text { management }\end{array}$ & $\begin{array}{r}\text { Table 2. } \\
\text { Number of students in } \\
\text { graduate courses } \\
\text { academic year } \\
\text { Total }\end{array}$ \\
\hline 13 & 14 & 14 & 41 \\
$2019 / 2020$ \\
\hline
\end{tabular}

\section{Pedagogical innovation in higher education}


the results show that ISAL implements active learning methodologies, even though the respondents have different opinions regarding the frequency of this implementation.

With reference to the methodologies implemented at ISAL, blended learning (teaching practice that combines classroom teaching with distance learning) is the methodology most mentioned by the respondents $(65.5 \%)$. It is important to refer that when this research was being carried out, the educational institutions were adopting a distance learning system due to the new coronavirus pandemic.

This question allowed respondents to mention more than one active learning methodology. Therefore, project work, cooperative and/or collaborative work, the incorporation of new technologies and targeted research were also mentioned by more than $40 \%$ of respondents. Case study (31.8\%), differentiated instruction (15.5\%), role play (11.5\%) and flipped classroom $(9.5 \%)$ were also pointed out by a lower percentage of the respondents.

In this regard, it is also important to analyse the frequency with which interdisciplinarity is promoted. Answers range from "never" (2\%) to "rarely" (4.7\%), "occasionally" $(39.2 \%)$, "frequently" (48.6\%) and "very often" (5.4\%).

\subsection{RQ2. How prepared and receptive are teachers and students for the implementation of these methods?}

The results show that the majority of the respondents feel prepared or duly trained to implement active learning methodologies, even if they display different levels of preparation. The level of preparation of the students and the training of teachers varies between low and very high. Almost half of the respondents $(46.6 \%)$ have an intermediate level of preparation, while $35.8 \%$ of them consider that they have a high level of preparation, $10.1 \%$ a very high level and only $7.4 \%$ a low level.

After analysing the respondents' level of preparation, it is also relevant to analyse their level of receptivity to innovative learning methodologies. The results suggest that their receptivity varies between "reduced" (3.4\%), "intermediate" (39.9\%), "high" (37.8\%) and "very high" $(18.9 \%)$. None of the respondents considered not being receptive to these methodologies.

The results also indicate that $91.9 \%$ of the respondents would like these methodologies to be implemented in the future, which means that only $8.1 \%$ of the respondents would not. More concretely, all teachers surveyed intend to implement innovative learning methodologies in the future. Only 12 out of the 137 students surveyed would not like these methodologies to be implemented. Therefore, the results show that, overall, students and teachers are receptive to innovation in the teaching and learning process, which is key to pedagogical success and students' integration into the job market.

\subsection{RQ3. What is the students' and teachers'perception of the pedagogical practices implemented?}

Respondents consider that the active methodologies implemented at ISAL contribute to the development of creativity, critical analysis and autonomy in the search for knowledge. Moreover, it encourages scientific research and the ability to work as a team. The results for RQ3 indicate that the methodologies applied at ISAL also contribute to the acquisition of global and articulated knowledge.

\subsection{RQ4. What obstacles does the implementation of these methodologies face?}

Respondents point out the size of the class(es) (57.4\% of the respondents), the layout of the rooms $(33.1 \%)$ and the lack of resources $(31.8 \%)$ as the main obstacles to the implementation of active learning methodologies. Although to a lesser extent, the lack of specific training was also reported by $20.9 \%$ of the respondents. 


\section{Discussion}

\subsection{RQ1. How frequent is the use of active methodologies in ISAL's degrees?}

As discussed in the literature review, pedagogical innovation needs to be strengthened in higher education and discussed by all those who participate in the teaching and learning process (Araújo and Belian, 2018). Therefore, the first step is for both teachers and students to recognize the need to innovate. Moreover, the results of this study suggest that teachers and students at ISAL recognize this need, since they attach relevance to pedagogical innovation.

Bearing in mind the aforementioned importance of innovation in education, da Silva (2018) recommends that higher education teachers use different active learning methodologies. The objective of these methodologies is to stimulate an active and constructive learning environment. Moreover, the results show that ISAL implements different active learning methodologies, which is in line with Silva's recommendation. Overall, the literature review highlights the importance of implementing these methodologies and the results suggest that ISAL recognizes that importance as well (according to $45.9 \%$ of the respondents, these methodologies are used frequently).

\section{$5.2 R Q 2$. How prepared and receptive are teachers and students for the implementation of these methods?}

The results suggest that the majority of the respondents feel prepared or duly trained to implement active learning methodologies, even if they display different levels of preparation. As a matter of fact, Casanova (2014) points out that pedagogical change and innovation require continuous training. This suggests that an investment in teachers' training is needed in order to better prepare them to adopt innovative methodologies.

In addition, the results indicate that the majority of the respondents $(91.9 \%)$ would like these methodologies to be implemented in the future. It is important to mention that all teachers surveyed intend to implement innovative learning methodologies in the future. These results are not in line with the literature review that highlights the resistance of higher education to pedagogical innovation, mentioning the fact that universities have long been consolidated as holders of knowledge and have been littleadapted to the structural changes that have occurred in the teaching process over time (LeiteandZabalza,2012;Masetto,2012). Therefore, theresults suggest that there has been an evolution in the way that higher education embraces innovation.

\subsection{RQ3. What is the students' and teachers' perception of the pedagogical practices implemented?}

Respondents consider that the active methodologies implemented at ISAL contribute to the development of creativity, critical analysis and autonomy in the search for knowledge, encourage scientific research and the ability to work as a team. These consequences of the implementation of active learning methodologies are consistent with the literature. When describing the emerging pedagogical models, which are focussed on the student's abilities, the authors state that innovative teaching methods encourage students to seek knowledge autonomously, developing creativity and critical analysis (Vieira et al., 2008; Attard et al., 2010). In a society in constant change like ours, students need to develop these skills, in order to be integrated into a very competitive job market, therefore the relevance of implementing innovative and active learning methodologies.

\subsection{RQ4. What obstacles does the implementation of these methodologies face?}

According to the literature, even though it is urgent to promote change and innovation in higher education, this process does not happen quickly or easily. It involves change in mentalities, continuous training and the existence of a reflective and critical culture (Casanova, 2014). 
Moreover, spaces need to be conducive to collaboration. This means that the classroom needs to be rethought (Feyfant, 2016). In line with the literature review, the respondents of this study point out the size of the classes and the layout of the rooms as the main obstacles to the implementation of active learning methodologies. In fact, having a large number of students ina room that does not promote collaboration and does not facilitate learning. Additionally, the respondents also mention the lack of resources and specific training as barriers to the implementation of activelearning methodologies. As mentioned, investing in teachers' training and resources is essential to the success of the teaching and learning process.

\section{Conclusions, limitations and suggestions for future research}

The aim of this study is to obtain a broader knowledge of pedagogical innovation practices in higher education applied to the real context of a private entity, ISAL. Even though the literature review highlights the resistance of higher education to change, the results indicate that both ISAL's teachers and students are receptive to pedagogical innovation, which translates into the implementation of active learning methodologies.

As for the methodologies implemented, the respondents highlight blended learning, project work, cooperative and/or collaborative work, the incorporation of new technologies and oriented research. The results also suggest that these methodologies contribute to the development of creativity, critical analysis and autonomy in the search for knowledge and provide the acquisition of global and articulated knowledge.

The results reveal that the respondents feel prepared or duly trained to implement active learning methodologies, even if they display different levels of preparation. However, they present the layout of the classrooms, the high number of students per class and the lack of resources as barriers to the implementation of active learning methodologies. Larger rooms, with a layout that allows group work and greater interaction between students, as well as access to a greater number of resources, would bridge these barriers and would facilitate the implementation of several active methodologies.

One of the main limitations of this study lies in the fact that it applies only to one educational institution, which is a private entity. Therefore, this study is not representative of the system of pedagogical innovation practices throughout the Portuguese territory. For this reason, it is suggested that future investigations apply this study to broader samples, which include other universities and polytechnics inside and outside the country, both public and private, so that the results obtained correspond to a broader reality, at the national or international level. This limitation is also related to the methodology used, since the conclusions cannot be generalized when adopting a case study methodology.

It is intended that this study contributes to broadening the readers' knowledge of active learning methodologies in the context of higher education and leads to the development and adoption of the innovative pedagogical methodologies analysed, given the importance of these practices for educational institutions. Furthermore, it is considered that there is still much research to carry out, taking into account the research gap in this scientific area.

\section{References}

Acar, O.A. and Tuncdogan, A. (2019), "Using the inquiry-based learning approach to enhance student innovativeness: a conceptual model", Teaching in Higher Education Critical Perspectives, Vol. 2517 Nos 24:7, pp. 895-909, available at: https://doi.org/10.1080/13562517.2018.1516636.

Alves, M.P. (2003), “Avaliação de competências. Mudar os nomes ou mudar as práticas?”, Revista Elo Especial, pp. 203-211.

Alves, M.P., Morgado, J., Lemos, A.R., Rodrigues, S. and Sá, S. (2012), “Innovative practices in higher education”, available at: https://www.semanticscholar.org/paper/Pr\%C $3 \%$ A1ticas-inovadoras- 
no-ensino-superior-Alves-Morgado/b45307046016cd306949bf7c5ef33af5b7cc7493 (accessed January 2020).

Amado, A., Cortez, P., Rita, P. and Moro, S. (2017), "Research trends on big data in marketing: a text mining and topic modeling based literature analysis", European Research on Management and Business Economics, Vol. 24, pp. 1-7, doi: 10.1016/j.iedeen.2017.06.002.
Pedagogical innovation in higher education

Anderson, G. (1993), Fundamentals of Educational Research, Falmer Press, London.

Andrews, J. and Higson, H. (2008), "Graduate employability, 'soft skills' versus 'hard' business knowledge: a European study", Higher Education in Europe, Vol. 33 No. 4, pp. 411-422.

Araújo, R. and Belian, R. (2018), "Concepções de professores universitários sobre inovação pedagógica”, Revista Internacional de Educação Superior, Vol. 4 No. 2, pp. 387-400, maio/ago.

Aristei, D., Vecchi, M. and Venturini, F. (2016), "University and inter-firm R\&D collaborations: propensity and intensity of cooperation in Europe", Journal of Technology Transfer, Vol. 41 No. 4, pp. 841-871, doi: 10.1007/s10961-015-9403-1.

Ascenzo, M.D. (2020), "Pedagogic alternatives in Italy after the second world war: the experience of the Movimento di cooperazione educativa and Bruno Ciari's new school in Bologna”, Espacio, Tiempo y Educación, Vol. 7 No. 1, pp. 69-87.

Attard, A., Di Iorio, E., Geven, K. and Santa, R. (2010), Student-centred Learning - Toolkit for Students, Staff and Higher Education Institutions, T4SCL Project Steering Group, Brussels, available at: http://www.esib.org/documents/publications/.

Behrens, M.A. (2005), O paradigma emergente e a prática pedagógica, Vozes, Petrópolis.

Biggs, J. and Tang, C. (2007), Teaching for Quality Learning at University - What the Student Does, 3rd ed., McGraw Hill Education/Open University Press, England.

Boavida, A.M. and Ponte, J.P. (2002), "Investigaçáo colaborativa: potencialidades e problemas", in GTI (Ed.), Reflectir e investigar sobre a prática profissional, APM, Lisboa.

Belther, J.M. (Org.) (2014), Didática I, Pearson Education do Brasil, São Paulo.

Casanova, M.P. (2014), "Avaliação da Formação Contínua de Professores: Uma Necessidade Emergente", Formação contínua. 20 anos 20 ideias em Ação, Revista do CFAECA, Almada: CFAECA, pp. 31-37, available at: http://issuu.com/almadaformarevista/docs/4almadaforma.

Cervantes, M. (2017), "Higher education institutions in the knowledge triangle", Foresight and STI Governance, Vol. 11 No. 2, pp. 27-42, doi: 10.17323/2500-2597.2017.2.27.42.

Chaudhary, R. (2017), "Demographic factors, personality and entrepreneurial inclination a study among Indian university students", Education and Training, Vol. 59 No. 2, pp. 171-187, doi: 10. 1108/ET-02-2016-0024.

da Silva, J.F. (2018), “Didática no Ensino Superior: estratégias de ensino adequadas à arte de ensinar”, Educação Por Escrito, Porto Alegre, Vol. 9 No. 2, pp. 204-219.

De Castro, L.S.V. (2020), "Translating teacher funds of identity into curricular Proposals for the EFL classroom: a model for student-teacher innovation and professional development", translating teacher Funds of identity into curricular Proposals for the EFL Classroom : a model for studentteacher innovation and", Journal of Language, Identity, and Education, Vol. 19 No. 1, pp. 25-41, doi: 10.1080/15348458.2019.1667239.

Delors, J. and Nanzhao, Z. (1998), Educação: um tesouro a descobrir, UNESCO, São Paulo, Cortez, Brasília.

Dias, S.J. (2005), Dilemas da educação superior no mundo globalizado: sociedade do conhecimento ou economia do conhecimento?, Casa do psicólogo, São Paulo.

Educause, (2012), "Things you should know about flipped classrooms", Ferreira, 2010, available at: http://net.educause.edu/ir/library/pdf/eli7081.pdf (accessed 19 July 2013).

Esteves, M. (2010), "Sentidos da inovação pedagógica no Ensino Superior", in Leite, C. (Ed.), Sentidos da pedagogia no Ensino Superior, CIIE/Livpsic, Porto, pp. 45-61. 
European Commission (2017), On A Renewed Eu Agenda for Higher Education, Communication from the commission to the European Parliament, the council, the European economic and social committee and committee of the regions, Brussels, available at: https:/ec.europa.eu/education/ sites/education/files/he-com-2017-247_en.pdf.

Fernandes, C.I. and Ferreira, J.J.M. (2013), "Knowledge spillovers: cooperation between universities and KIBS", $R$ and D Management, Vol. 43 No. 5, pp. 461-472, doi: 10.1111/radm.12024.

Feyfant, A. (2016), "La différenciation pédagogique en classe”, Dossier de veille de l'IFÉ, n. 113, ENS de Lyon, Lyon.

Flick, U. (2005), Métodos Qualitativos na Investigação Científica, monitor, Lisboa.

Flipped Classroom Field Guide (2014), Portal Flipped Classroom Field Guide, available at: http://www. cvm.umn.edu/facstaff/prod/groups/cvm/@pub/@cvm/@facstaff/documents/content/cvm_ content_454476.pdf (accessed 15 abr. 2014).

Franco, M. and Pinho, C. (2018), "A case study about cooperation between university research centres: knowledge transfer perspective”, Suma de Negocios, Vol. 2017, doi: 10.1016/j.jik.2018.03.003.

Freinet, C. (2004), Pedagogia do bom senso, 7th ed., Martins Fontes, São Paulo.

Freire, P. (2014), Pedagogia da autonomia: saberes necessários à prática educativa, 49th ed., Paz e Terra, Rio de Janeiro.

Fresne, R. (1994), La Pédagogie Différenciée: Mode D’emploi, Nathan, Paris.

Fukugawa, N. (2016), "Knowledge creation and dissemination by Kosetsushi in sectoral innovation systems: insights from patent data”, Scientometrics, Vol. 109 No. 3, pp. 2303-2327, doi: 10.1007/ s11192-016-2124-x.

Gadotti, M. (1995), Concepção dialética da educação: um estudo introdutório, 9th ed., Cortez, São Paulo.

Gil, A.C. (2011), Metodologia do ensino superior, 4th ed., Atlas, São Paulo.

Gil, A.C. (2015), Didática do ensino superior, Atlas, São Paulo, [E-book].

Haydt, R.C.C. (2006), Curso de didática geral, Ática, São Paulo.

Houle, C.O. (1996), The Design of Education, 2nd ed., Jossey-Bass, San Francisco.

Kaplan, A. (2014), "European management and European business schools: insights from the history of business schools", European Management Journal. doi: 10.1016/j.emj.2014.03.006.

Kenski, V.M. (2012), Educação e tecnologia: o novo ritmo da informação, Papirus, Campinas.

Knowles, M.S. (1980), The Modern Practice of Adult Education: From Pedagogy to Andragogy, 2nd ed., Cambridge Books, New York, NY.

Koman, G. and Kundrikova, J. (2016), "Application of Big data technology in knowledge transfer process between business and academia", Procedia Economics and Finance, Vol. 39 November 2015, pp. 605-611, doi: 10.1016/S2212-5671(16)30305-7.

Lévy, P. (2010), As tecnologias da inteligência: o futuro do pensamento na era da informática, 2nd ed., Vol. 34, Editora, São Paulo.

Lee, C., Hallak, R. and Sardeshmukh, S.R. (2016), "Innovation, entrepreneurship, and restaurant performance: a higher-order structural model", Tourism Management, Vol. 53, pp. 215-228, doi: 10.1016/j.tourman.2015.09.017.

Leite, C. and Ramos, K. (2010), "Questões da formação pedagógico-didática na sua relação com a profissionalidade docente universitária: Alguns pontos para debate", in Leite, C. (Ed.), Sentidos da pedagogia no Ensino Superior, CIIE/Livpsic, Porto, pp. 29-43.

Leite, C. and Zabalza, M. (2012), Ensino superior: inovação e qualidade na docência, Centro de Investigação e Intervenção Educativas, Porto.

Li, W. (2017), "Can intellectual property rights protection and governmental R\&D investment promote Chinese enterprises' R\&D investment?", Knowledge Management Research and Practice, Vol. 15 No. 4, pp. 551-559, doi: 10.1057/s41275-017-0076-4. 
Liblik, A.M.P. (2012), Aprender didática, ensinar didática, InterSaberes, Curitiba.

Malheiros, B.T. (2012), Didática geral, LTC, Rio de Janeiro, FREIRE, R. A. A didática no ensino superior. São Paulo: Cengage, 2012.

Martins, G., Gomes, C., Brocardo, J., Pedroso, J., Carrillo, J., Silva, L. and Rodrigues, S. (2017), Perfil Dos Alunos A Saida Perfil Dos Alunos, pp. 1-30, available at: http://www.dge.mec.pt/sites/default/ files/Curriculo/Projeto_Autonomia_e_Flexibilidade/perfil_dos_alunos.pdf.

Masetto, M.T. (2012), Docência na universidade, 11th ed., Papirus, Campinas.

Melo, A.S. (2017), "Processo de Bolonha e o repensar do papel do ensino superior: um ensino centrado na aquisição de competências", O ensino superior pós-Bolonha: tempo de balanço, tempo de mudança. Livro de Atas, Faculdade de Psicologia e Ciências da Educação. Universidade de Coimbra, pp. 93-98, available at: https://estudogeral.sib.uc.pt/bitstream/10316/37062/1/O\% 20ENSINO \% 20SUPERIOR\%20PÓS\%20BOLONHA.pdf.

Merriam, S.B. (2017), "Adult learning theory: evolution and future Directions", PAACE Journal of Lifelong Learning, Vol. 26, pp. 21-37.

Miranda, E.M. (2007), "Novos conceitos em novos contextos", Revista de Estudos Politécnicos, Vol. V No. 8, pp. 161-182, ISSN: 1645-9911, available at: http:/www.scielo.mec.pt/pdf/tek/n8/v5n8a08.pdf.

Moran, J.M., Masetto, M.T. and Behrens, M.A. (2013), Novas tecnologias e mediação pedagógica, 21st ed., Papirus, Campinas.

Morgado, J.C. and Tomaz, C. (2010), "Curricular articulation and educational success: a research partnership", in Estrela, A., Viana, I.C., Costa, A., Serrano, A.M., Silva, A.M., Sampaio, B., Silva, C., Candeias, I., Sousa, J., Morgado, J.C., Palhares, L., Gomes, M.J., Magalhães, M.J., Correia, N., Pinheiro, R., Vilaça, T. and Timmerman, V. (Eds), School and the World of Work. Proceedings of the XVII AFIRSE Colloquium, Universidade de Lisboa (CD-Rom), Lisbon, available at: https:// ria.ua.pt/bitstream/10773/4017/1/4725.pdf (accessed 1 March 2020).

Morin, E. (2013), A Religação Dos Saberes: O Desafio Do Século XXI, 11th ed., Bertrand Brasil, Rio de Janeiro.

Nóvoa, A. and Amante, L. (2015), "Em busca da Liberdade. A pedagogia universitária do nosso tempo", REDU. Revista de Docencia Universitaria, Vol. 13 No. 1, pp. 21-34, Obtido de:available at: http://red-u.net/redu/files/journals/1/articles/956/public/956-3939-1-PB.pdf.

Peixoto, A.G. (2016), "O uso de metodologias ativas como ferramenta de potencialização da aprendizagem de diagramas de caso de uso", Periódico Científico Outras Palavras, Vol. 12 No. 2, pp. 35-50.

Perraudeau, M. (1997), Les cycles et la différenciation pédagogique, 2nd éd., Armand Colin, Paris.

Perrenoud, P. (2005), La pédagogie à l'école des différences: fragments d'une sociologie de l'échec, 3rd éd., ESF, Issy-Les-Moulineaux.

Piletti, C. (2010), Didática geral, 24th ed., Ática, São Paulo.

Ramos, F., Costa, N., Tavares, J. and Huet, I. (2006), "A staff development program for promoting change in higher education teaching and learning practices", in Kumar, D. and Turner, J. (Eds), Education for the 21st century - Impact of ICT and digital resources, International Federation for Information Processing, Springer, Boston, Vol. 210, pp. 405-409.

Ramos, A., Delgado, F., Afonso, P., Cruchinho, A., Pereira, P., Sapeta, P. and Ramos, G. (2013), "Implementação de novas práticas pedagógicas no Ensino Superior", Revista Portuguesa de Educação, Vol. 26 No. 1, pp. 115-141, available at: https://www.redalyc.org/pdf/374/ 37428913006.pdf.

Rodrigues, A.L. and Patrocínio, T. (2018), "A Importância da pedagogia na qualidade das instituições de ensino superior”, Revista FORGES, Vol. 5 No. 1, pp. 33-56, available at: https://repositorio.ul. $\mathrm{pt} /$ handle/10451/38194?locale $=$ en.

Rodrigues, L.P., Moura, L.S. and Testa, E. (2011), "O tradicional e o moderno quanto à didática no ensino superior”, Revista Científica do ITPAC, Vol. 4 No. 3, Araguaína, Pub.5, Julho.

\section{Pedagogical innovation in higher education}

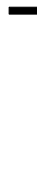


Sales, S.R. and Leal, R.E.G. (2018), "Práticas pedagógicas inovadoras na formação docente: ciborguização do currículo do curso de pedagogia”, Revista Internacional de Ensino Superior, Vol. 4 No. 1, pp. 6-24.

Sampieri, R.H., Collado, C.F. and Lucio, P.B. (2006), Metodología de la investigación, McGrawHill, México.

Serbanica, C.M., Constantin, D.L. and Dragan, G. (2015), "Uiversity-industry knowledge transfer and network patterns in Romania: does knowledge supply fit SMEs' regional profiles?”, European Planning Studies, Vol. 23 No. 2, pp. 292-310, doi: 10.1080/09654313.2013.862215.

Teixeira, S.J., Lopes Casteleiro, C.M., Rodrigues, R. and Guerra, M. (2018), "Entrepreneurial intentions and entrepreneurship in European countries", International Journal of Innovation Science, Vol. 10 No. 1, pp. 22-42, doi: 10.1108/IJIS-07-2017-0062.

Teixeira, S.J., Veiga, P.M. and Fernandes, C.A. (2019), "The knowledge transfer and cooperation between universities and enterprises", Knowledge Management Research and Practice, pp. 1-12, doi: 10.1080/14778238.2018.1561166.

Valente, J.A. (2014), "Blended learning e as mudanças no ensino superior: a proposta da sala de aula invertida”, Educar em Revista, No. 4, pp. 79-97, Universidade Federal do Paraná Paraná, Brasil.

Vieira, F., Mamede, A. and Lima, C. (2008), "Staging pedagogy for autonomy: two plays", in Jiménez Raya, M. and Lamb, T. (Eds), Pedagogy for Autonomy in Language Education in Europe: Theory, Practice and Teacher Education, Authentik, Dublin, pp. 106-125.

Yin, R.K. (2003), Case Study Research: Design and Methods, 3rd ed., Sage, Thousand Oaks, CA.

Zheng, W., Xu, M., Chen, X. and Dong, Y. (2017), "Who is shaping entrepreneurial experience? A multiple case study of Chinese entrepreneurial learning", Management Decision, Vol. 55 No. 7 , pp. 1394-1409, doi: 10.1108/MD-06-2016-0370.

\section{Further reading}

Amem, B.M.V. and Nunes, L.C. (2006), "Tecnologias de Informação e Comunicação: contribuições para o processo interdisciplinar no ensino superior TT - The contribution of information and communication technologies to higher education according to an interdiscipline proposal", Revista Brasileria de Educacao Médica, Vol. 30, pp. 171-180, available at: http://www.scielo.br/ scielo.php?script $=$ sci_arttext\&pid=S0100-55022006000300009.

Cândido, F.F. (2010), "Práticas pedagógicas e inovação na instituição de ensino: uma abordagem psicopedagógica com foco na aprendizagem", Revista Psicopedagogia, Vol. 27 No. 83, pp. 262-272, available at: http://pepsic.bvsalud.org/scielo.php?script=sci_arttext\&pid=S0103$84862010000200011 \& \operatorname{lng}=\mathrm{pt \& nrm}=$ iso\&tlng $=$ pt.

Cardoso, A. (1999), “A receptividade à inovação e a formação dos professores”, Revista Electrónica Interuniversitaria de Formación Del Profesorado, Vol. 2 No. 1, p. 17.

da Silva, J.F. (2019), "Didática no Ensino Superior: estratégias de ensino adequadas à arte de ensinar", Educação Por Escrito, Vol. 9 No. 2, p. 204, doi: 10.15448/2179-8435.2018.2.31275.

de Seixas, E.P.A., de Araújo, M.V.P., de Brito, M.L.A. and Fonseca, G.F. (2017), "Dificuldades E Desafios Na Aplicação De Metodologias Ativas No Ensino De Turismo: Um Estudo Em Instituição De Ensino Superior”, Turismo - Visão e Ação, Vol. 19 No. 3, p. 566, doi: 10.14210/ rtva.v19n3.p566-588.

Dos Santos, A.S. and Da Silva, G.S. (2017), "Interdisciplinaridade no ensino superior: desafios e diálogos na academia”, RELACult - Revista Latino-Americana de Estudos Em Cultura e Sociedade, Vol. 3 No. 1, p. 5, doi: 10.23899/relacult.v3i1.370.

Guimarães, J.D.C. and Lima, M.A.M. (2016), "Empreendedorismo educacional: reflexões para um ensino docente diferenciado", Revista Pensamento Contemporâneo Em Administração, Vol. 10, No 2, p. 34, doi: 10.12712/rpca.v10i2.715.

Inês, M., Vitoria, C. and Rigo, R.M. (2018b), Ensino universitário: uma análise da motivação, pp. 326-346. 
Maltabarova, N.A., Kokoshko, A.I., Abduldayeva, A.A., Shanazarov, N.A. and Smailova, G.T. (2019), "Innovation technologies in student's independent activity and creativity development: the case of medical education", International Journal of Emerging Technologies in Learning, Vol. 14 No. 11, pp. 32-40, doi: 10.3991/ijet.v14i11.10341.

Merriam, S.B. (2001), The New Update on Adult Learning Theory, 1st ed., Jossey-Bass, San Francisco.

Pedagogical innovation in higher education

Oliveira, I. and Courela, C. (2014), "Mudança e inovação em educação: o compromisso dos professores", Interaç̧ões, Vol. 9 No. 27, pp. 97-117.

Palvalin, M., Vuori, V. and Helander, N. (2018), "The relation between knowledge transfer and productivity in knowledge work", Knowledge Management Research and Practice, Vol. 16 No. 1, pp. 118-125, doi: 10.1080/14778238.2018.1428067.

Paula, A. and de Oliveira, P. (2001), Que variáveis estarão relacionadas com as atitudes dos professores face à inovação pedagógica, nomeadamente no que concerne aos novos papéis, definidos segundo a perspectiva da educação permanente?.

Velásquez, J.A.T., Arias, A.V., Hernández, J.B., Díez-Echavarría, L.F., Marín, M.L.U. and Pérez, F.O.M. (2018), "Characterization of entrepreneurial intention in university students as from systemic entrepreneurship intention model: a case study", Cuadernos de Gestion, Vol. 18 No. 2, pp. 95-114, doi: 10.5295/cdg.160670jt.

Zabalza, M. (2003), Competencias docentes del profesorado universitario: Calidad y desarrollo profesional, Narcea, Madrid.

\section{Corresponding author}

Sergio Jesus Teixeira can be contacted at: sergio.teixeira@isal.pt 
1. Respondents' profile

1.1.Student

1.2.Teacher

1.3.Age

2. Municipality

Select your municipality.

\begin{tabular}{|l|l|}
\hline & Calheta \\
\hline & Câmara de Lobos \\
\hline & Funchal \\
\hline & Machico \\
\hline & Porto Moniz \\
\hline & Ponta de Sol \\
\hline & Porto Santo \\
\hline & Ribeira Brava \\
\hline & Santa Cruz \\
\hline & Santana \\
\hline & São Vicente \\
\hline
\end{tabular}

3. Field of study/teaching

(If several,please select the main field)

\begin{tabular}{|l|l|}
\hline & TOURISM \\
\hline & BUSINESS MANAGEMENT \\
\hline & $\begin{array}{l}\text { HOTEL ORGANISATION AND } \\
\text { MANAGEMENT }\end{array}$ \\
\hline
\end{tabular}

4. From your point of view, how relevant is pedagogical innovation?

\begin{tabular}{|c|c|c|c|c|}
\hline 1 & 2 & 3 & 4 & 5 \\
\hline Considering that: (1.Not relevant, 2. Slightlyrelevant, 3. Relevant, 4.Very relevant, 5.
\end{tabular}

Extremely relevant)

5. Which active methodologies do you apply or are applied in the classroom or outside?

\begin{tabular}{|l|l|}
\hline & $\begin{array}{l}\text { Learning methodology that combines face-to-face and distance learning } \\
\text { (blended learning) }\end{array}$ \\
\hline & Project work \\
\hline & Differentiated instruction \\
\hline & Flipped classroom \\
\hline & Cooperative and collaborative work \\
\hline & Targeted research \\
\hline & Case study \\
\hline & Role play \\
\hline & Incorporation of new technologies in the educational context
\end{tabular}


6. How frequently are active learning methodologies implemented in the course unit(s) that you attend/teach?

\begin{tabular}{|c|c|c|c|c|}
\hline 1 & 2 & 3 & 4 & 5 \\
\hline Considering that: (1. Never, 2. Rarely, 3. Occasionally, 4. Frequently, 5. Very often)
\end{tabular}

7. How prepared/trained are you for the implementation of these methods?

\begin{tabular}{|c|c|c|c|c|}
\hline 1 & 2 & 3 & 4 & 5 \\
\hline \multicolumn{2}{|c|}{ Considering that: (1. Not prepared, 2. Slightly prepared, 3. Prepared, 4.Very }
\end{tabular}
prepared, 5. Extremely prepared)

8. How frequently is interdisciplinarity promoted?

\begin{tabular}{|c|c|c|c|c|c|}
\hline 1 & & 2 & 3 & 4 & 5 \\
\hline
\end{tabular}
Considering that: (1. Never, 2. Rarely, 3. Occasionally, 4. Frequently, 5. Very often)

9. What are the main obstacles to the implementation of these methodologies?

\begin{tabular}{|l|l|}
\hline & Size of the class(es) \\
\hline & Layout of the room(s) \\
\hline & Lack of resources \\
\hline & Lack of specific training \\
\hline
\end{tabular}

10. How receptive are you to these methodologies?

\begin{tabular}{|c|c|c|c|c|}
\hline 1 & 2 & 3 & 4 & 5 \\
\hline
\end{tabular}
receptive, 5. Extremely receptive)

11. From your point of view, what are the results of the implementation of active learning methodologies in your institution?

\begin{tabular}{|c|}
\hline Acquisition of global and integrated knowledge (interdisciplinarity) \\
\hline $\begin{array}{l}\text { Ability to mobilise knowledge to solve problems and to create and implement } \\
\text { ideas and projects }\end{array}$ \\
\hline Development of creativity and critical analysis \\
\hline Promotion of scientific research \\
\hline Ability to work as a team \\
\hline Autonomy in the search for knowledge \\
\hline $\begin{array}{l}\text { Acquisition of core competencies - competencies that involve factual, } \\
\text { conceptual, procedural and metacognitive knowledge;mental, physicaland } \\
\text { cognitive skills; organizational and social skills; and ethical values }\end{array}$ \\
\hline Creation of aculture of autonomy and responsibility \\
\hline Education for mutual understanding between people from different cultures \\
\hline Development of an inclusive citizenship \\
\hline Self-development \\
\hline Curiosity, reflection and innovation \\
\hline
\end{tabular}

12. Would you like innovative learning methodologies to be implementedin the future?

\begin{tabular}{|l|l|}
\hline & Yes \\
\hline & No \\
\hline
\end{tabular}

Pedagogical innovation in higher education 